\title{
Adverse drug reactions in patients on aspirin therapy with concomitant antihypertensive medication in a tertiary care hospital of deccan plateau
}

\author{
Tamilisetti Vidya Sagar ${ }^{1}$, Sanjay Kumar,", Pramila Nayak ${ }^{3}$ \\ ${ }^{1}$ Assistant Professor, ${ }^{2,3}$ Professor, Dept. of Pharmacology, ${ }^{1,2}$ GSL Medical College, Rajahmundry, Andhra Pradesh ${ }^{3}$ IMS \& SUM \\ Hospital, SOA University, Bhubaneswar, India
}

*Corresponding Author:

Email: sanjaykumarimssum@gmail.com

\begin{abstract}
Introduction: To know adverse drug reactions when Aspirin is prescribed with Antihypertensive medications.

Materials and Methods: Prospective observational study conducted in a tertiary care hospital, total 60 patients of age group 18 to 65 years were included in the study, It is a 12 week study, clinical examination done at enrollment and with subsequent follow up at 4,8 and 12 weeks,Base line investigations done at enrollment and at 12 weeks, ADR monitoring done at each follow up Casuality assessment of all ADRs was done by Naranjo ADR scale

Results: Out of 45 patients who experienced adverse effects, causality assessment shows that Aspirin is responsible for producing ADRs in 15 patients and in remaining 30 patients, Aspirin interaction is likely cause for ADRs, Incidence of adverse effects is $40 \%$ in Aspirin with concomitant Betablocker therapy and 26\% in Aspirin with thiazide diuretics and $16 \%$ in aspirin with ACE inhibitors or Calcium channel blockers

Conclusion: This study shows increased incidence of Adverse drug reactions (though these are mild ADRs) when Aspirin is added to Betablockers and Thiazide diuretics in treatment of hypertension,Incidence of ADRs is high in elderly patients,
\end{abstract}

Keywords: Aspirin, Betablockers, Calcium channel blockers, ACE inhibitors, Thiazide diuretics, Naranjo scale.

\section{Introduction}

Aspirin ${ }^{1}$ also known as acetylsalicylic Acid is a salicylate drug, often used as an analgesic to relieveminor aches and pains, as an antipyretic to reduce fever,and as an anti-inflammatory medication. ${ }^{2}$

Aspirin alsohas an antiplatelet effect by inhibiting the production ofthromboxane, which under normal circumstances bindsplatelet molecules together to create a patch over damagedwalls of blood vessels. Because the platelet patchcan become too large and also block blood flow, locallyand downstream, aspirin is also used longterm, at lowdoses, to help prevent heart attacks, strokes, and blood clot formation in people at high risk of developing bloodclots. ${ }^{3}$

It has also been established that low doses of aspirinmay be given immediately after a heart attack to reduce the risk of another heart attack or of the death of cardiac tissue. ${ }^{4,5}$

The main side effects of aspirin are gastrointestinal ulcers, stomach bleeding, and ringing in the ears, especiallywith higher doses. In children and adolescents, aspirinis not recommended for flu-like symptoms or viral illnesses, because of the risk of Reye's syndrome. ${ }^{6}$

Aspirin is part of a group of medications called nonsteroidal anti-inflammatory drugs (NSAIDs), but differs from most other NSAIDs in the mechanism of action. Though it and others with similar structure, called the salicylates, have similar effects (antipyretic, anti inflammatory, analgesic) to the other NSAIDs and inhibit the same enzyme cyclooxygenase (COX), aspirin does so in an irreversible manner and, unlike others, affects more the COX-1 variant than the COX-2 variant of the enzyme. ${ }^{7}$
The active ingredient of Aspirin was first discovered from the bark of the willow tree in 1763 by Edward Stone of Wadham College, Oxford University. He had discovered salicylic acid, the active metabolite of aspirin ${ }^{8}$ Aspirin was first synthesized by Felix Hoffmann, a chemist with the German company Bayer in 1897.9.10

Aspirin is one of the most widely used medications in the world, with an estimated 40,000 tonnes of it being consumed each year. ${ }^{11}$ It is on the World Health Organization'sList of Essential Medicines, a list of the most important medication needed in a basic health system. $^{12}$

The increasing numbers of people being exposed to aspirin has also led to the awareness of the significant potential harm arising from the adverse haemorrhagic effects of aspirin (e.g. gastrointestinal and intracranial bleeds). Hence there is need to critically consider the evidence behind the therapeutic indications for aspirin, and decide whether the anticipated benefit outweighs the potential for harm.

There are several mechanisms by which drugs may interact, ${ }^{13,14}$ and most of these mechanisms can be categorized as pharmacokinetic (involving intestinal absorption, distribution, metabolism, and elimination) or as pharmacodynamic, or as additive toxicity, respectively.

Vast majority of hypertensive patients is treated with antihypertensive drugs for many years. Other therapeutic agents are frequently used simultaneously, thus giving rise to the possibility of drug-drug interactions.

The potential for drug-drug interactions increases with rising age, since elderly patients receive larger 
number of drugs, but also because the renal excretion of several therapeutic agents is impaired in the elderly, as a result of diminishing kidney function. ${ }^{15,16}$

Present study conducted to investigate occurrence of adverse drug reactions when patients are prescribed Aspirin with regular antihypertensive medication

\section{Objective}

To know adverse drug reactions when Aspirin is prescribed with Antihypertensive medications.

\section{Materials and Methods}

Prospective observational study conducted in a tertiary care hospital. Total 60 patients were included in the study, patients of age between 18 to 65 years were included, patients of either sex included in the study, Males-24, females-36.

\section{Inclusion criteria}

1. Patients receiving Aspirin for any indication.

2. Above 18 years.

3. Concomitant antihypertensive medication.

\section{Exclusion criteria}

1. Pre-existing thyroid diseases, renal and liver.

2. Terminally ill.

3. Pregnant and lactating.

Duration of study: 12 weeks

\section{Study procedure}

1. Written informed consent was obtained from each patient.

2. Clinical examination done at enrolment and with subsequent follow up at 4,8 and 12 weeks.

3. Base line investigations done at enrolment and at 12 weeks, ADR monitoring done at each follow up.

Table 1. Naranjo's scale

\begin{tabular}{|c|l|c|c|c|}
\hline S. No & \multicolumn{1}{|c|}{ Questionnare } & Yes & No & Don't know \\
\hline 1 & $\begin{array}{l}\text { Are there previous conclusion } \\
\text { reports on this reaction? }\end{array}$ & +1 & 0 & 0 \\
\hline 2 & $\begin{array}{l}\text { Did the adverse event appeared } \\
\text { after suspect drug was } \\
\text { administered? }\end{array}$ & +2 & -1 & 0 \\
\hline 3 & $\begin{array}{l}\text { Did adverse event improve when } \\
\text { drug was discontinued? }\end{array}$ & +1 & 0 & 0 \\
\hline 4 & $\begin{array}{l}\text { Did adverse event reappeared } \\
\text { when drug was readministered? }\end{array}$ & +2 & -1 & 0 \\
\hline 5 & $\begin{array}{l}\text { Are there alternative causes that } \\
\text { could solely have caused } \\
\text { reaction? }\end{array}$ & -1 & +2 & 0 \\
\hline 6 & $\begin{array}{l}\text { Did reaction reappear when } \\
\text { placebo was given? }\end{array}$ & -1 & +1 & 0 \\
\hline 7 & $\begin{array}{l}\text { Was drug detected in blood in a } \\
\text { concentration known to be toxic? }\end{array}$ & +1 & 0 & 0 \\
\hline 8 & $\begin{array}{l}\text { Was reaction more severe when } \\
\text { drug was increased or less severe } \\
\text { when dose was decreased? }\end{array}$ & +1 & 0 & 0 \\
\hline 9 & $\begin{array}{l}\text { Did patient have similar reaction } \\
\text { to similar drug in any previous } \\
\text { exposure? }\end{array}$ & +1 & 0 & 0 \\
\hline 10 & $\begin{array}{l}\text { Was adverse event confirmed by } \\
\text { objective evidence? }\end{array}$ & +1 & 0 & 0 \\
\hline
\end{tabular}

Scoring

$>9=$ definite ADR

5-8=probable ADR

1-4=possible ADR

$0=$ doubtful ADR

Investigations: Base line investigations: Complete blood picture, blood Urea, serum Creatinine, serum glutamic oxaloacetic transaminase (SGOT) \& Serum glutamic Pyruvic Transaminase (SGPT),Urine analysis- for Albumin, Sugar, Microscopy, bleedingtime, clotting time and lipid profile\& 12 lead ECGare done for all the patients and they are repeated at the end of study

\section{Data analysis}

Using paired test with baseline values.

Casuality assessment of all ADRs was done by Naranjo ADR scale. 


\section{Observation and Results}

Table 2. Specific adverse drug reactions reported with Aspirin

\begin{tabular}{|c|l|c|}
\hline S. No. & \multicolumn{1}{|c|}{ ADR } & No.of patients \\
\hline 1 & Abdominal pain & 3 \\
\hline 2 & Fatigue & 2 \\
\hline 3 & Nausea & 2 \\
\hline 4 & Tinnitus & 2 \\
\hline 5 & Constipation & 2 \\
\hline 6 & Insomnia & 3 \\
\hline 7 & Rash & 1 \\
\hline
\end{tabular}

Table 3: Causality for Aspirin for reported ADRs

\begin{tabular}{|c|c|c|}
\hline $\begin{array}{c}\text { No. of Probable } \\
\text { reactions }\end{array}$ & $\begin{array}{c}\text { No.of possible } \\
\text { reactions }\end{array}$ & $\begin{array}{c}\text { No.of doubtful } \\
\text { reactions }\end{array}$ \\
\hline $40 \%$ & $60 \%$ & 0 \\
\hline
\end{tabular}

Table 4: Number of patients to have ADRs in Aspirin with concomitant medications

\begin{tabular}{|l|c|}
\hline Aspirin with Beta-blockers & 12 \\
\hline Aspirin with Calcium channel blockers & 5 \\
\hline Aspirin with ACE inhibitors & 5 \\
\hline Aspirin with Thiazide diuretics & 8 \\
\hline
\end{tabular}

Table 5: ADRs due to Aspirin with Concomitant medications

\begin{tabular}{|l|c|c|c|c|c|c|}
\hline & Headache & Dizziness & Nausea & Tinnitus & Fatigue & Insomnia \\
\hline $\begin{array}{l}\text { Beta- } \\
\text { blockers }\end{array}$ & 2 & 2 & 2 & 2 & 2 & 2 \\
\hline $\begin{array}{l}\text { Calcium } \\
\text { channel } \\
\text { blockers }\end{array}$ & 1 & 1 & 0 & 1 & 1 & 1 \\
\hline $\begin{array}{l}\text { ACE } \\
\text { inhibitors }\end{array}$ & 1 & 1 & 1 & 1 & & 1 \\
\hline $\begin{array}{l}\text { Thiazide } \\
\text { diuretics }\end{array}$ & 1 & 1 & 1 & 1 & 4 & 0 \\
\hline
\end{tabular}

Table 6: Distribution of adverse effects in age group

\begin{tabular}{|l|c|c|c|}
\hline $\begin{array}{c}\text { Age } \\
\text { (Years) }\end{array}$ & $\begin{array}{c}\text { No.of } \\
\text { patients }\end{array}$ & $\begin{array}{c}\text { No.of patients } \\
\text { with ADRs }\end{array}$ & Percentage \\
\hline $21-25$ & 5 & 2 & $40 \%$ \\
\hline $26-30$ & 5 & 2 & $40 \%$ \\
\hline $31-35$ & 5 & 2 & $40 \%$ \\
\hline $36-40$ & 4 & 2 & $50 \%$ \\
\hline $41-45$ & 4 & 2 & $50 \%$ \\
\hline $46-50$ & 8 & 7 & 87.5 \\
\hline $51-55$ & 10 & 9 & $90 \%$ \\
\hline $56-60$ & 13 & 13 & $100 \%$ \\
\hline $61-65$ & 6 & 6 & $100 \%$ \\
\hline Total & 60 & 45 & \\
\hline
\end{tabular}

\section{Discussion}

This study is prospective open labelled study done in a tertiary care hospital, total number of patients observed are 60, patients taking Aspirin with concomitant Antihypertensive medication are included in the study.
Aspirin is commonly prescribed along with antihypertensive medications and it appears to increase number of adverse drug reactions though these are mild.

In this study, out of 60 patients, 45 patients experienced adverse effects and no adverse effects are seen in 15 patients 
Out of 45 patients who experienced adverse effects, causality assessment shows that Aspirin is responsible for producing ADRs in 15 patients and in remaining 30 patients, Aspirin interaction is likely cause for ADRs.

Incidence of adverse effects is $40 \%$ in Aspirin with concomitant Betablocker therapy and 26\% in Aspirin with thiazide diuretics and $16 \%$ in aspirin with ACE inhibitors or Calcium channel blockers.

Incidence of ADRs is more in age group more than 45 years and in age group more than 55 years, $100 \%$ ADR incidence is seen.

Incidence of adverse effects like headache, dizziness, fatigue, nausea, tinnitus and insomnia is more in patients with Aspirin with concomitant Betablockers and thiazide diuretics and it is less in aspirin with concomitant ACE inhibitors or calcium channel blockers.

\section{Conclusion}

This study shows increased incidence of adverse drug reactions when Aspirin is added to Betablockers and Thiazide diuretics in treatment of hypertension, Incidence of ADRs is high in elderly patients

\section{Conflict of Interest: Nil}

\section{References}

1. Zorprin, Bayer Buffered Aspirin (aspirin) dosing, indications, interactions, adverse effects, and more". Medscape Reference. WebMD.Retrieved 3 April 2014.

2. Brayfield, A, ed. (14 January 2014). “Aspirin”.Martindale: The Complete Drug Reference. Pharmaceutical Press. Retrieved 3 April 2014.

3. Lewis, H. D., Davis, J. W., Archibald, D. G., Steinke,W. E., Smitherman, T. C., Doherty Je, J. E., Schnaper, H. W., Lewinter, M. M., Linares, E., Pouget, J. M., Sabharwal, S. C., Chesler, E., Demots, H. (1983). "Protective Effects of Aspirin against Acute Myocardial Infarction and Death in Men with Unstable Angina". New England Journal of Medicine 309 (7):396-

403.doi:10.1056/NEJM198308183090703. PMID 6135989.

4. Julian, D G; D A Chamberlain; S J Pocock (24 September 1996). "A comparison of aspirin and anticoagulation following thrombolysis for myocardial infarction (the AFTER study): a multicentre unblinded randomised clinical trial". BMJ (British Medical Journal) 313 (7070):1429-1431. doi:10.1136/bmj.313.7070.1429. PMC 2353012.PMID 8973228.

5. Krumholz, H. M., Radford, M. J., Ellerbeck, E. F., Hennen, J., Meehan, T. P., Petrillo, M., Wang, Y., Kresowik, T. F., Jencks, S. F. (1995). "Aspirin in the treatment of acute myocardial infarction in elderly Medicare beneficiaries. Patterns of use and outcomes". Circulation 92 (10):2841-2847. doi:10.1161/01.CIR.92.10.2841. PMID 7586250.

6. Macdonald S (2002). "Aspirin use to be banned in under 16-year olds”. BMJ 325 (7371): 988. doi:10.1136/bmj.325.7371.988/c. PMC 1169585.PMID 12411346.

7. Burke, Anne; Smyth, Emer; FitzGerald, Garret A. (2006). "26: Analgesic Antipyretic and Antiinflammatory Agents". Goodman and Gilman's the pharmacologicalbasis of therapeutics (11 ed.). New York: McGraw- Hill. pp. 671-716. ISBN 978-0-07-142280-2.

8. Stone Edmund (1763). An Account of the Success of the Bark of the Willow in the Cure of Agues. In a Letter to the Right Honourable George Earl of Macclesfield, President of R. S. from the Rev. Mr. Edmund Stone, of Chipping-Norton in Oxfordshire".Philosophical Transactionsof the Royal Society of London 53:195-200. doi:10.1098/rstl.1763.0033. JSTOR 105721.

9. Sneader, W. (2000). "The discovery of aspirin: A reappraisal”. BMJ (Clinical research ed.) 321 (7276): 1591- 1594. doi:10.1136/bmj.321.7276.1591. PMC 1119266.PMID 11124191.

10. Schrör, Karsten (2009). Acetylsalicylic acid.Wiley.ISBN 978-3-527-32109-4.

11. Warner, T. D.; Warner TD, Mitchell JA (2002).Cyclooxygenase-3 (COX-3): filling in the gaps towarda COX continuum? extquotedbl. Proceedings of the NationalAcademy of Sciences of the United States of America 99(21):13371-3. doi:10.1073/pnas.222543099. PMC129677.PMID 12374850.

12. WHO Model List of EssentialMedicines". World Health Organization. October 2013. Retrieved 22 April 2014.

13. Hansten $\mathrm{PhD}$. Important drug interactions. In: Katzung BG (Ed). Basic and clinical pharmacology. Prentice-Hall Int, Englewood Cliffs NJ, USA, 5th Ed, 1992;pp 931 - 42

14. Stockley IH. Drug interactions.Pharmaceutical Press, London, 5th Ed, 1999.

15. Popplewell PY, Henschke PJ. Acute admissions to a geriatric assessment unit.Med J Aust 1982;1:343 - 4.

16. Williamson J, Chopin JM. Adverse reactions to prescribed drugs in the elderly: a multicenter investigation. Age Ageing 1980;9:73 - 80. 